\title{
The effects of brain-derived neurotrophic factor on insulin signal transduction in the liver of diabetic mice
}

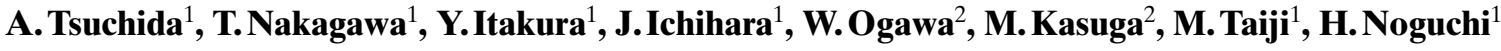 \\ ${ }^{1}$ Sumitomo Pharmaceuticals, Osaka, Japan \\ ${ }^{2}$ The Second Department of Internal Medicine, Kobe University School of Medicine, Kobe, Japan
}

\section{Abstract}

Aim/hypothesis. We previously reported that repeated subcutaneous or intracerebroventricular injection of brain-derived neurotrophic factor (BDNF) reduces blood glucose concentrations in obese diabetic $\mathrm{C} 57 \mathrm{BL} / \mathrm{KsJ}-d b / d b$ mice. In this study, we assessed the effects of BDNF on insulin action in peripheral tissues of diabetic mice.

Methods. First, brain-derived neurotrophic factor $(20 \mathrm{mg} / \mathrm{kg}$ ) was subcutaneously given to male $d b / d b$ mice for 14 days and then the insulin-stimulated tyrosine phosphorylation of insulin receptors and insulin-stimulated phosphatidylinositol (PI) 3-kinase activity in peripheral tissues was assessed. Second, we examined the effects of a single subcutaneous or intracerebroventricular brain-derived neurotrophic factor injection on insulin responsiveness in liver and skeletal muscle of streptozotocin (STZ)-induced diabetic mice. Third, the effects of brain-derived neurothrophic factor on insulin action were also examined in cultured cells.

Results. Repeated injection of BDNF to $d b / d b$ mice for 14 days enhanced insulin-stimulated tyrosine phosphorylation of insulin receptors in liver and insulin-stimulated PI 3-kinase activity in liver, skeletal muscle and interscapular brown adipose tissue. We then examined the rapid effect of BDNF on insulin signalling in vivo. A single subcutaneous or intracerebroventricular injection of BDNF rapidly increased insulin-stimulated tyrosine phosphorylation of insulin receptors and PI 3-kinase activity in liver of STZmice. No direct effect of brain-derived neurothrophic factor was observed on insulin signalling in primary cultured hepatocytes, L6 muscle cells or 3T3-L1 adipocytes. Brain-derived neurothrophic factor did not affect either glucose uptake or gluconeogenesis in these cells.

Conclusion/interpretation. These data indicate that brain-derived neurothrophic factor rapidly enhances insulin signal transduction in liver and shows hypoglycaemic action in diabetic mice. [Diabetologia (2001) 44: 555-566]

Keywords Neurotrophic factor, insulin responsiveness, glucose uptake, diabetic mice, insulin signalling.
Received: 10 July 2000 and in revised form: 28 December 2000

Corresponding author: Mutsuo Taiji, PhD, Sumitomo Pharmaceuticals Co. Ltd., Discovery Research Laboratories II, 3-1-98 Kasugadenaka, Konohana-ku, Osaka 554-0022, Japan Abbreviations: BDNF, brain-derived neurothrophic factor; PI 3-kinase, phosphatidylinositil 3-kinase; STZ, streptozotocin; aCSF, artificial cerebrospinal fluid; $\alpha$-MEM, $\alpha$-Minimal essential medium; DMEM, Dulbecco's modified Eagle's medium; FCS, fetal calf serum; 2-DG, 2-deoxy glucose.
Brain-derived neurotrophic factor (BDNF) is a member of the neurotrophin-family which includes nerve growth factor, neurotrophin-3 and neurotrophin- $4 / 5$ [1-4]. BDNF promotes neurite outgrowth and trophic support to certain neurons in the central and peripheral nervous systems. The efficacy of BDNF in the treatment of neurological disorders has been demostrated elsewhere $[1,5-7]$. We have previously found that BDNF reduces food intake and lowers blood glucose in obese diabetic models such as $\mathrm{C} 57 \mathrm{BL} / \mathrm{KsJ}-d b / d b$ mice [8-10]. This was the first evi- 
dence that a neurotrophin possesses a pleiotrophic effect and functions in the endocrine system as well as in the nervous system.

As an extension of that work we have analysed the hypophagic effect of BDNF on blood glucose in more detail. With a new pellet pair-feeding apparatus, developed by us to regulate feeding precisely between control and BDNF-treated groups, we were able to show that BDNF has a significant hypoglycaemic action in hyperphagic diabetic mice apart from the reduction of food intake [11]. With long-term treatment, the hypoglycaemic action of BDNF was found to be stronger in younger, more hyperinsulinaemic $d b / d b$ mice than in older, less hyperinsulinaemic $d b /$ $d b$ mice [11]. In addition, BDNF enhanced insulindependent hypoglycaemic action in stretozotocin (STZ)-induced Type I diabetic mice [11]. These results suggest that BDNF reduces blood glucose by either enhancing insulin responsiveness or possibly ameliorating insulin resistance in peripheral tissues of diabetic animals.

Insulin resistance in peripheral tissues is a pathological characteristic of patients with Type II (non-insulin-dependent) diabetes mellitus and clinically very important when trying to improve the glucose metabolism of these patients $[12,13]$. Insulin resistance is also present in diabetic animal models such as $d b / d b$ mice, $o b / o b$ mice and Zucker fatty rats [14-16]. Insulin-stimulated activation of insulin receptor tyrosine kinase and phosphatidylinositol (PI) 3-kinase are altered in the peripheral tissues of such diabetic animals [17-19] and this could be at least partly responsible for the reduced insulin action. Thus, the enhancement of insulin responsiveness and the amelioration of insulin resistance are promising profiles for anti diabetic drugs. Thiazolidinediones, a newly-developed class of anti diabetic drugs, have in fact been reported to have such features [20-22].

Therefore, in order to clarify the action mechanism responsible for BDNF's hypoglycaemic efficacy, it is very important to analyse in detail the effect of BDNF on insulin sensitivity in peripheral tissues. Our objective in this study was to examine whether BDNF modulates the insulin-stimulated activation of insulin receptors and PI 3-kinase in both insulin resistant $d b / d b$ mice and insulin deficient streptozotocin-induced mice. We also assessed the direct action of BDNF on cultured hepatocytes, adipocytes and muscle cells.

\section{Materials and methods}

Animals. Male C57BL/KsJ- $d b / d b$ mice were obtained from Clea Japan (Tokyo, Japan). Treatment in these mice began at 8 weeks of age. Male C57BL/6Ncrj mice were obtained from Charles River Japan (Tokyo, Japan). These mice were treated with streptozotocin at 6 weeks of age. Male Wistar rats were purchased from Japan SLC (Hamamatsu, Japan). All animals were housed in group cages and maintained in a daily cycle of 12 hours light and 12 hours darkness. Food (CE-2, Clea Japan, Tokyo, Japan) and water were given freely except to mice in the fasting experiments. All animal experiments were conducted according to the guidelines of the Sumitomo Pharmaceuticals Committee on Animal Research.

Materials. Human recombinant BDNF ( $\mathrm{N}$-terminal methionine-free) was from Regeneron Pharmaceuticals (Tarrytown, N. Y., USA). PBS containing $0.01 \%$ Tween 80 and $1 \%$ mannitol was used as a vehicle for subcutaneous injection of BDNF. Artificial cerebrospinal fluid (aCSF; $0.166 \mathrm{~g} / 1 \mathrm{CaCl}_{2}, 7.014 \mathrm{~g} / \mathrm{l}$ $\mathrm{NaCl}, 0.298 \mathrm{~g} / \mathrm{l} \mathrm{KCl}, 0.203 \mathrm{~g} / \mathrm{l} \mathrm{MgCl}_{2} / 6 \mathrm{H}_{2} \mathrm{O}$ and $2.10 \mathrm{~g} / \mathrm{l} \mathrm{NaH}-$ $\mathrm{CO}_{3}$ ) was used as a vehicle for intracerebroventricular injection. Human regular insulin (Novolin R) was from Novo Nordisk (Copenhagen, Denmark). Metformin (dimethylbiguanide) was from Sigma (St. Louis, Mo., USA). $\alpha$-Minimal essential medium ( $\alpha$-MEM), Dulbecco's modified Eagle's medium (DMEM) and fetal calf serum (FCS) were from Gibco BRL (Grand Island, N.Y. USA). 2-deoxy[1,2- $\left.{ }^{3} \mathrm{H}\right]$ glucose, $[\gamma$ ${ }^{32} \mathrm{P}$ ]ATP and ACSII were from Amersham Life Science (Buckinghamshire, England). Protein $\mathrm{G}$ sepharose beads were from Amersham Pharmacia Biotech (Uppsala, Sweden). Monoclonal anti-phosphotyrosine antibody (4G10), polyclonal antiIRS-1 antibody and polyclonal anti-IRS-2 antibody were from Upstate Biotechnology (Lake Placid, N. Y. USA) and monoclonal anti-phosphotyrosine antibody (PY20), monoclonal anti-insulin receptor $\beta$ subunit antibody (29B4) and polyclonal anti-insulin receptor $\beta$ subunit antibody (C-19) were from Santa Cruz Biotechnology (Santa Cruz, Calif., USA).

Cell culture. Rat L6 muscle cells were kindly given by Dr A. Klip (the Hospital for Sick Children, Toronto, Canada). The cells were seeded on 24-well plates $\left(5 \times 10^{4}\right.$ cells/well $)$ or on a $100 \mathrm{~mm}$ dish $\left(1 \times 10^{6} \mathrm{cells} / \mathrm{dish}\right)$ and cultured in $\alpha$-MEM containing $10 \%$ FCS under a humidified atmosphere $\left(5 \% \mathrm{CO}_{2}\right)$. Confluent cells were then cultured for 2 days in $\alpha$-MEM containing $2 \%$ FCS and used in the experiment.

Mouse 3T3-L1 adipocytes were purchased from ATCC (Rockville, Md., USA). The cells were seeded on 24-well gelatin-coated plates $\left(2 \times 10^{4}\right.$ cells/well $)$ or on a $100 \mathrm{~mm}$ gelatincoated dish $\left(1 \times 10^{6}\right.$ cells/dish $)$ and cultured in DMEM containing $10 \%$ FCS under a humidified atmosphere containing $\left(5 \% \mathrm{CO}_{2}\right)$. Confluent cells were then cultured for 2 days in DMEM containing $0.5 \mathrm{mmol} / \mathrm{l}$ isobutylmethylxantine, $2.5 \mu \mathrm{mol} / \mathrm{l}$ dexamethazone, $8 \mu \mathrm{g} / \mathrm{ml}$ biotin, $10 \mu \mathrm{g} / \mathrm{ml}$ insulin and $10 \%$ FCS. The media was changed 2 days later to DMEM containing $8 \mu \mathrm{g} / \mathrm{ml}$ biotin and $10 \%$ FCS and replaced every other day thereafter. The cells were then used in the experiment 8 to 11 days after confluence.

A primary culture of rat hepatocytes was isolated from male Wistar rats by collagenase perfusion methods [23]. The cells were seeded on 24 -well plates $\left(3 \times 10^{5}\right.$ cells/well $)$ or on a $100 \mathrm{~mm}$ dish $\left(6 \times 10^{6}\right.$ cells/dish $)$ and cultured for $16 \mathrm{~h}$ in Williams medium E containing $10 \mathrm{nmol} / \mathrm{l}$ dexamethazone and $5 \%$ FCS under a humidified atmosphere $\left(5 \% \mathrm{CO}_{2}\right)$.

Insulin signal transduction in cultured cells. The above cells cultured in $100 \mathrm{~mm}$ dishes were serum starved for $24 \mathrm{~h}$ and pre-incubated with BDNF (100 $\mathrm{ng} / \mathrm{ml})$ for 2 and $24 \mathrm{~h}$ before insulin stimulation. The cells were then incubated with insulin $(100 \mathrm{nmol} / \mathrm{l})$ or saline for $10 \mathrm{~min}$ at $37^{\circ} \mathrm{C}$. They were washed 2 times with ice-cold PBS and immediately frozen in liquid nitrogen.

2-deoxyglucose uptake in vitro. The L6 muscle cells and 3T3L1 adipocytes cultured in 24-well plates were pre-incubated 
with $\operatorname{BDNF}(0,10,100$ and $1000 \mathrm{ng} / \mathrm{ml})$ for $24 \mathrm{~h}$ before the glucose uptake experiment. They were then washed 3 times and incubated in Krebs-Ringer-phosphate buffer ( $\mathrm{pH}$ 7.4) for $30 \mathrm{~min}$ at $37^{\circ} \mathrm{C}$. The cells were next incubated with insulin $(100 \mathrm{nmol} / \mathrm{l})$ or saline for $15 \mathrm{~min}$. The glucose uptake experiment was started by adding 2 -deoxy $\left[1,2-{ }^{3} \mathrm{H}\right]$ glucose $(0.5 \mu \mathrm{Ci} /$ well $)$ and unlabelled 2-deoxyglucose $(0.1 \mathrm{mmol} / \mathrm{l}$ final concentration). Glucose uptake was terminated by removing the reaction medium and washing the cells 3 times with ice-cold PBS containing $0.1 \mathrm{mmol} / \mathrm{l}$ phloretin. Cells were suspended with trypsin/EDTA and counted in a liquid scintillator (ACS II).

Effect of BDNF on glucose production in vitro. Isolated hepatocytes cultured in 24-well plates were then washed twice with PBS and incubated with $\operatorname{BDNF}(0,1,10$ and $100 \mathrm{ng} / \mathrm{ml})$ or metformin $(10 \mathrm{mmol} / \mathrm{l})$ in glucose free Hank's solution containing $0.1 \%$ fructose, $100 \mathrm{nmol} / \mathrm{l}$ glucagon for $6 \mathrm{~h}$ at $37^{\circ} \mathrm{C}$. Newly produced glucose in the medium was measured by the Glucose $\mathrm{C}$ II-Test Wako (Mutarotase-glucose oxidase method, Wako Chemical, Osaka, Japan).

Effect of repeated BDNF injection on tyrosine phosphorylation of insulin receptors in $\mathrm{db} / \mathrm{db}$ mice. We gave BDNF $(20 \mathrm{mg} / \mathrm{kg} /$ day) or vehicle subcutaneously to $d b / d b$ mice for 14 days. On day 14, tyrosine phosphorylation of insulin receptors and phosphatidylinositol (PI) 3-kinase activity in liver, hindlimb skeletal muscle, interscapular brown adipose tissue and epididymal adipose tissue were analysed with insulin stimulation [138 units/ $\mathrm{kg}$ (about 5 units/mouse); intravenous injection into tail vein] after $16 \mathrm{~h}$ fasting. Saline instead of insulin was injected to the negative control group without insulin stimulation. Four groups of $d b / d b$ mice were analysed: (1) vehicle control group without insulin stimulation; (2) vehicle control group with insulin stimulation; (3) BDNF-treated group without insulin stimulation; (4) BDNF-treated group with insulin stimulation. Mice that received insulin or saline were decapitated $3 \mathrm{~min}$ after the injection. The liver, hindlimb skeletal muscle, interscapular brown adipose tissue and epididymal adipose tissue were then immediately excised and frozen in liquid nitrogen.

Effect of a single BDNF injection on insulin signal transduction in streptozotocin-induced diabetic mice. Diabetes was induced in $\mathrm{C} 57 \mathrm{BL} / 6 \mathrm{Ncrj}$ mice by two consecutive daily intraperitoneal injections of streptozotocin (STZ, $200 \mathrm{mg} / \mathrm{kg}$ ) dissolved in citrate buffer ( $\mathrm{pH}$ 5.5). On the third day after the last STZ injection, insulin signalling was analysed after a single subcutaneous injection of BDNF or vehicle in STZ-induced diabetic mice (STZ-mice). Mice were fasted after BDNF or vehicle treatment. To assess the effect of a single injection of BDNF on insulin signal transduction under basal conditions, mice were decapitated without insulin stimulation $2 \mathrm{~h}$ after a single BDNF $(70 \mathrm{mg} / \mathrm{kg}, \mathrm{s} . \mathrm{c}$.) or vehicle treatment. The liver and hindlimb skeletal muscle were then immediately excised and frozen in liquid nitrogen. Next, the effect of BDNF was investigated on insulin signalling under insulin-stimulated conditions. Two hours after a single BDNF $(70 \mathrm{mg} / \mathrm{kg}$, s.c.) or vehicle treatment, with human regular insulin ( $1 \mathrm{unit} / \mathrm{kg})$ was injected into the tail vein of STZ-mice. These mice were then decapitated $3 \mathrm{~min}$ and $10 \mathrm{~min}$ after insulin injection. Similarly, the liver and hindlimb skeletal muscle were then immediately excised and frozen in liquid nitrogen.

In the case of intracerebroventricular BDNF injection, STZ-mice were anaesthetized with diethyl ether, the bregma was identified and $5 \mu \mathrm{g}$ BDNF/mouse $(3 \mu \mathrm{l} / \mathrm{shot})$ or aCSF was injected into the lateral ventricle. Experimental protocols except for injection of BDNF were the same as those described above.
Immunoprecipitation and western blotting. Frozen tissues or cells were homogenized in ice-cold lysis buffer $(20 \mathrm{mmol} /$ TRIS-HCl (pH 7.4), 0.15 mol/1 NaCl, 1 \% NP-40, $0.1 \%$ sodium deoxycholate, $5 \mathrm{mmol} / \mathrm{l}$ EDTA, $10 \mathrm{mmol} / \mathrm{l}$ sodium fluoride, $2 \mathrm{mmol} / \mathrm{l}$ sodium orthovanadate, $1 \mathrm{mmol} / \mathrm{l}$ phenylmethylsulfonyl fluoride, $10 \mu \mathrm{g} / \mathrm{ml}$ aprotinin and $10 \mu \mathrm{g} / \mathrm{ml}$ leupepsin). Homogenates were centrifuged and equal protein amounts of supernatants were immunoprecipitated with anti-insulin receptor $\beta$-subunit antibody (29B4) and protein $\mathrm{G}$-sepharose. The immunoprecipitates were studied with SDS-PAGE and western blot analysis using anti-phosphotyrosine antibody (4G10) or anti-insulin receptor $\beta$-subunit antibody (C-19). The blots were quantified by densitometry.

Phosphatidylinositol (P1) 3-kinase activity. Frozen tissues or cells were homogenised in ice-cold lysis buffer [20 mmol/l TRIS-HCl (pH 8.0), $0.137 \mathrm{~mol} / \mathrm{l} \mathrm{NaCl}, 1 \mathrm{mmol} / \mathrm{l} \mathrm{MgCl} 2$, $1 \mathrm{mmol} / 1 \mathrm{CaCl}_{2}, 10 \%$ glycerol, $1 \% \mathrm{NP}-40,1 \mathrm{mmol} / 1$ sodium orthovanadate, $1 \mathrm{mmol} / \mathrm{l} \mathrm{PMSF}$ and $1 \mathrm{mmol} / \mathrm{l}$ dithiothreitol (DTT)]. Homogenates were centrifuged, and equal protein amounts of supernatants were immunoprecipitated with antiphosphotyrosine antibody (PY20), anti-IRS-1 antibody, or anti-IRS-2 antibody and then protein G-sepharose. Immunoprecipitates were washed twice with PBS containing $1 \%$ NP40, twice with $0.1 \mathrm{~mol} / \mathrm{l}$ TRIS- $\mathrm{HCl}$ ( $\mathrm{pH}$ 7.4) containing $0.5 \mathrm{mmol} / \mathrm{L} \mathrm{LiCl}$ and twice with $10 \mathrm{mmol} / \mathrm{l}$ TRIS-HCl $(\mathrm{pH} 7.4)$ containing $0.1 \mathrm{~mol} / \mathrm{l} \mathrm{NaCl}$. The pellets were suspended in $50 \mathrm{mmol} / \mathrm{l}$ hydroxyethylpiperazin-ethanesulphonic acid HEPES) (pH 7.1) containing $0.2 \mathrm{mg} / \mathrm{ml} \mathrm{PI,} 1 \mathrm{mmol} / \mathrm{l}$ EGTA and $1 \mathrm{mmol} / \mathrm{l}$ sodium phosphate. The reaction was then started by adding $5 \mu \mathrm{Ci}\left[\gamma^{32} \mathrm{P}\right] \mathrm{ATP}$, and $250 \mu \mathrm{mol} / \mathrm{l} \mathrm{ATP}$ and $50 \mathrm{mmol} / \mathrm{l}$ $\mathrm{MgCl}_{2}$. After $6 \mathrm{~min}$ at room temperature $1 \mathrm{~N} \mathrm{HCl}$ and chloroform:methanol (1:1) were added to terminate the reaction. The samples were centrifuged and the lower organic phase was removed and applied to a silica gel thin layer chromatography plate coated with $1 \%$ potassium oxalate and $2 \mathrm{mmol} / \mathrm{l}$ EDTA. The plate was developed in chloroform:methanol:5 N ammonia (9:7:2), dried and visualised using a BAS2000 bio-imaging analyser (Fuji Photo Film, Tokyo, Japan).

Blood glucose. Blood samples were collected from tail vein and blood glucose was measured by the Glucose CII-Test Wako (Wako Chemical, Osaka, Japan).

Statistical analysis. All data are presented as means \pm SD. Differences between individual groups were analysed by Student's $t$-test. Statistical calculations were carried out using SAS software (SAS Institute, Cary, N.C., USA). A $p$ value of less than 0.05 was considered statistically significant.

\section{Results}

Long-term effect of BDNF injection on tyrosine phosphorylation of insulin receptors. We have previously shown that the repeated injection of BDNF reduces blood glucose concentration in $d b / d b$ mice [8-11]. Furthermore, the hypoglycaemic effect of BDNF was found to be stronger in younger, more hyperinsulinaemic $d b / d b$ mice than in older, less hyperinsulinaemic animals [8]. This suggests that BDNF produces its hypoglycaemic effect in $d b / d b$ mice by enhancing insulin responsiveness or alleviating insulin resistance or both. To examine whether there is an actual im- 
Table 1. Effect of repeated BDNF injection on blood glucose concentration in $d b / d b$ mice

\begin{tabular}{llllll}
\hline & \multicolumn{5}{l}{ Days } \\
\cline { 2 - 6 } & 0 & 3 & 6 & 9 & 12 \\
\hline Vehicle & $309 \pm 49$ & $324 \pm 57$ & $360 \pm 51$ & $370 \pm 60$ & $324 \pm 60$ \\
BDNF & $307 \pm 52$ & $227 \pm 38^{\mathrm{a}}$ & $185 \pm 26^{\mathrm{a}}$ & $158 \pm 17^{\mathrm{a}}$ & $134 \pm 16^{\mathrm{a}}$ \\
\hline BDNF $(20 \mathrm{mg} / \mathrm{kg})$ & or vehicle was given subcutaneously to $\mathrm{db} /$ \\
$\mathrm{db}$ mice for 14 days. Blood glucose concentration was mea- \\
sured during the treatment period. Data are shown as \\
means \pm SD for 13 or 14 mice. a $p<0.01$ vs vehicle: Student's $t$ \\
test
\end{tabular}

provement in insulin responsiveness we next analysed insulin signal transduction in the peripheral tissues of $d b / d b$ mice that received repeated subcutaneous injection of BDNF $(20 \mathrm{mg} / \mathrm{kg})$ for 14 days. The injection of BDNF for 14 days significantly reduced blood glucose concentrations in $d b / d b$ mice (Table 1$)$. On day 14 , three minutes after intravenous treatment with insulin or saline, the liver, hindlimb skeletal muscle, interscapular brown adipose tissue and epididymal adipose tissue were excised and subjected to western blot analysis. The tissue extracts were immunoprecipitated with anti-insulin receptor $\beta$ subunit $(\operatorname{IR} \beta)$ antibody and the blots were detected with anti-phosphotyrosine antibody after electrophoresis (Fig.1 A, C, E, G). Without insulin injection, only faint tyrosine-phosphorylated bands were observed in each tissue from $d b / d b$ mice given vehicle or BDNF and there was no significant difference in phosphorylation between vehicle-treated mice and BDNF-treated mice (Fig. 1 B, D, F, H). Next, 3 min after intravenous injection with insulin $(138 \mathrm{U} / \mathrm{kg})$, tyrosine phosphorylation of insulin receptors was clearly detected in each tissue from $d b / d b$ mice who had been given vehicle. After repeated injection of BDNF, insulin-stimulated tyrosine phosphorylation of insulin receptors in the livers of $d b / d b$ mice were significantly increased by 2.6-fold compared with those of vehicle-treated mice (Fig. 1B). Furthermore, there was no statistically significant difference but a tendency to increase insulin-stimulated tyrosine phosphorylation in skeletal muscles and interscapular brown adipose tissue from $d b / d b$ mice given BDNF when compared with those of vehicle-treated mice (1.2-fold in each tissue) (Fig.1D, F). In contrast, no change was observed in insulin-stimulated tyrosine phosphorylation of epididymal adipose tissue in vehicle-treated or BDNF-treated mice (Fig. $1 \mathrm{H}$ ). We also measured the $\operatorname{IR} \beta$ content in each tissue by western blotting with anti-IR $\beta$ antibody using the same immunoprecipitates. There was no significant difference in tissue IR $\beta$ content between the $d b / d b$ mice given vehicle and those given BDNF (Fig. 1 A, C, E, G).

Long-term effect of BDNF injection on phosphatidylinositol 3-kinase activity in $\mathrm{db} / \mathrm{db}$ mice. To study the effect of BDNF on insulin-triggered signalling, phosphatidylinositol (PI) 3-kinase activity was also analysed in the peripheral tissues (liver, hindlimb skeletal muscle, interscapular brown adipose tissue and epididymal adipose tissue) after repeated subcutaneous injection of BDNF $(20 \mathrm{mg} / \mathrm{kg})$ for 14 days. Extracts of these tissues were immunoprecipitated with anti-phosphotyrosine antibody and PI 3-kinase activity in each immunoprecipitate was measured (Fig. 2 A, C, E, G). Without insulin injection, no significant difference in PI 3-kinase activity was observed between tissues of $d b / d b$ mice given vehicle and those given BDNF (Fig. 2B, D, F, H). On the other hand, insulin-stimulated PI 3-kinase activity in liver, skeletal muscle and interscapular brown adipose tissue of $d b / d b$ mice given BDNF was significantly increased by 1.6-fold, 1.8-fold and 1.9-fold, respectively, compared with $d b / d b$ mice given vehicle (Fig. 2 B, D, F). These findings indicate that repeated injection of BDNF enhances insulin responsiveness in periphereal tissues of $d b / d b$ mice. No significant difference in insulin-stimulated PI 3-kinase activity in epididymal adipose tissue was observed between mice given vehicle and those given BDNF (Fig. 2H).

Rapid effect of subcutaneous BDNF injection on tyrosine phosphorylation of insulin receptors in streptozotocin-treated mice. The fact that BDNF showed a hypoglycaemic effect in several diabetic animals raises another possibility, namely that long-term treatment of BDNF alleviates glucose toxicity and enhances insulin responsiveness. We therefore decided to study the rapid effect of BDNF on insulin responsiveness in peripheral tissues in vivo.

Previously we have shown that BDNF in combination with insulin rapidly enhances the hypoglycaemic effect of insulin in streptozotocin (STZ)induced diabetic mice [11]. No such effect was observed with a single BDNF injection [11]. In this study, we examined the rapid effect of BDNF on tyrosine phosphorylation of insulin receptors using this STZ-mice model. Two hours after subcutaneous injection of BDNF or vehicle, insulin was intravenously injected into STZ-mice. Insulin receptor tyrosine residues were phosphorylated by insulin treatment in both liver and skeletal muscle from STZ-mice given vehicle (Fig.3). Compared with these mice, tyrosine phosphorylation of insulin receptors was significantly enhanced in livers from STZ-mice given BDNF at 3 and 10 min after insulin stimulation (1.7-fold and 3.8-fold, respectively). In contrast, BDNF showed no effect on tyrosine phosphorylation of insulin receptors in skeletal muscle. There was no significant difference in the IR $\beta$ content of liver and skeletal muscle between STZmice given vehicle and those given BDNF (Fig. 3 A, C). 
A

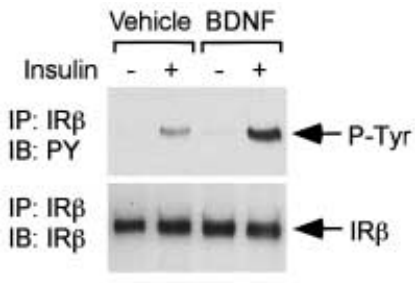

C

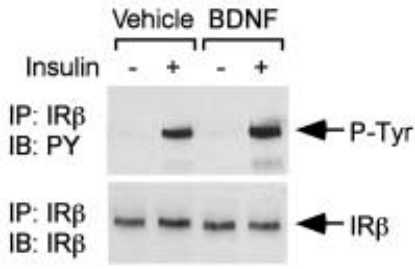

$\mathbf{E}$

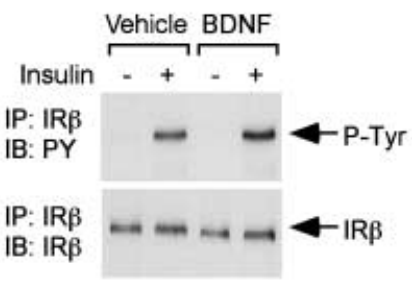

G

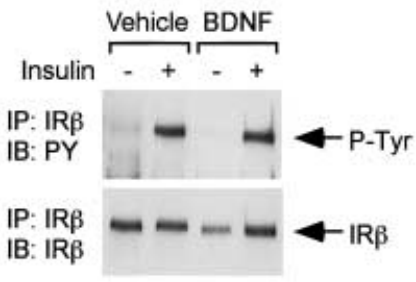

B

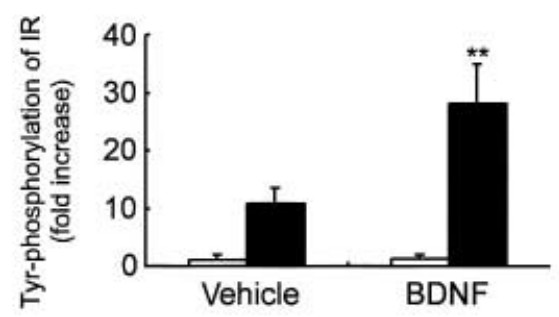

D

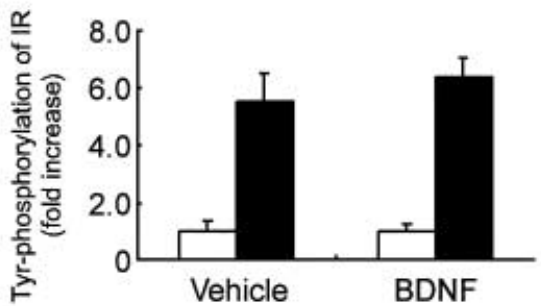

$\mathbf{F}$

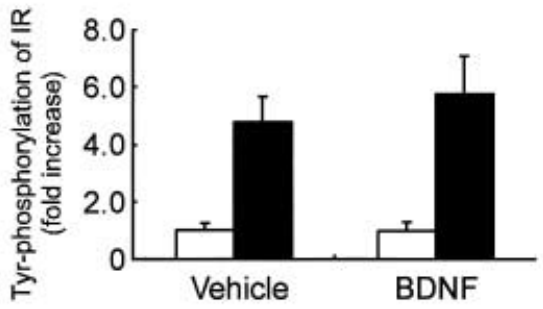

H

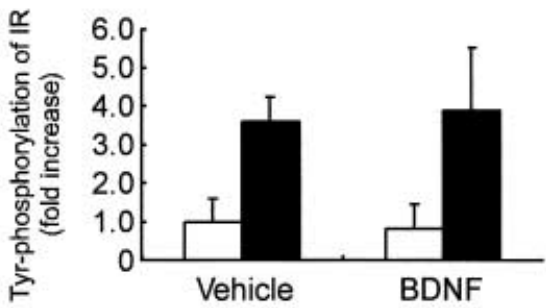

Rapid effect of subcutaneous BDNF injection on phosphatidylinositol 3-kinase activity in streptozotocin-induced diabetic mice. PI 3-kinase activity was also analysed in peripheral tissues from STZ-mice $2 \mathrm{~h}$ after a single subcutaneous injection of BDNF or vehicle. Ten minutes after insulin injection, PI 3-kinase activity was significantly increased by 1.8 -fold in livers from STZ-mice given BDNF compared with those given vehicle (Fig. 4A, B). Three minutes after insulin injection a 1.5-fold increase of PI 3-kinase activity was observed in livers from STZ-mice given BDNF compared with those given vehicle (Fig. 4 A, B). Insulin treatment increased PI 3-kinase activity in skeletal muscle, but there was no further enhancement with BDNF (Fig. 4 C, D).

Direct effect of BDNF on insulin signalling in cultured hepatocytes, L6 muscle cells and 3T3-L1 adipocytes. To clarify the action mechanism of BDNF on peripheral tissues, we studied the direct effect of BDNF on 
A

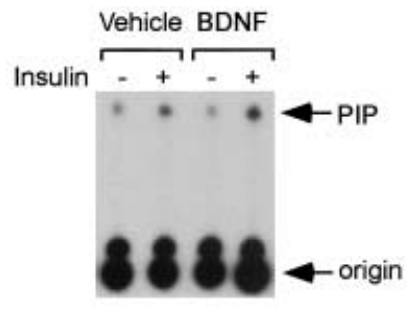

C

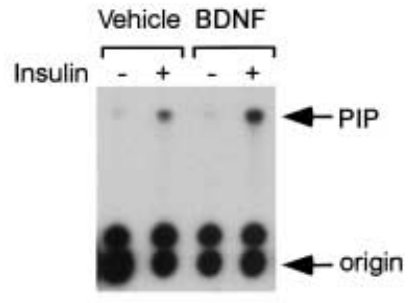

E

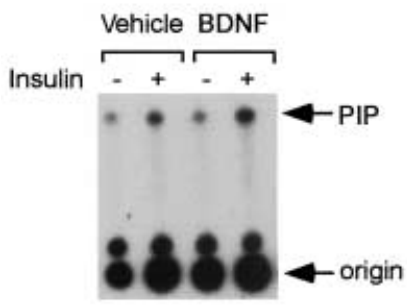

G

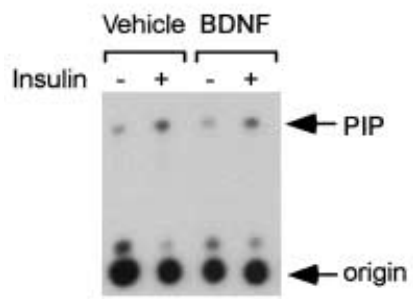

B

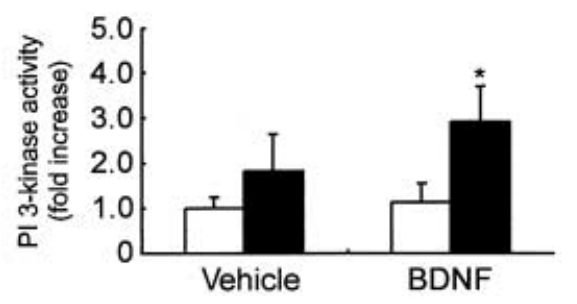

D

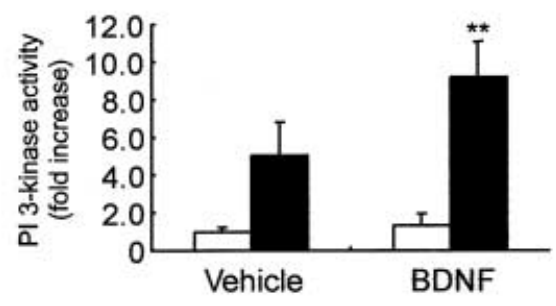

$\mathbf{F}$

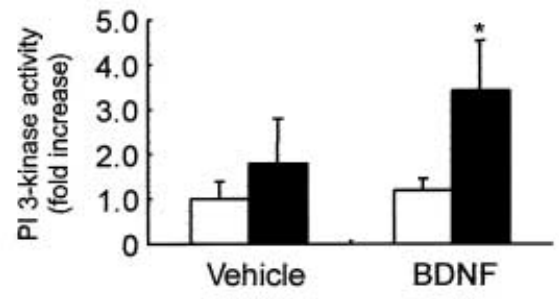

H

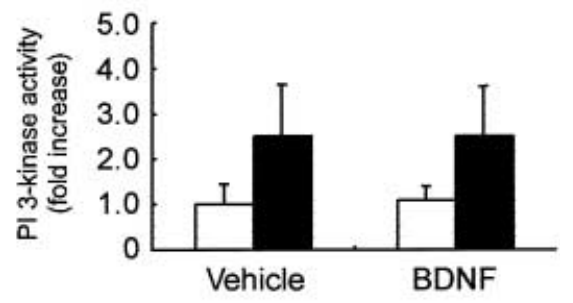

surement of tyrosine phosphorylation of insulin receptor and PI 3-kinase activity. With insulin stimulation there was an increase in both tyrosine phosphorylation of insulin receptor and PI 3-kinase activity in each cell. BDNF did not affect either tyrosine phosporylation of insulin receptor or PI 3-kinase activity in insulin-treated cultured cells (Fig.5). The basal activity of these parameters was not altered with BDNF treatment (Fig.5).

Direct effect of BDNF on glucose uptake in L6 muscle cells and 3T3-L1 adiopocytes and glucose output in cultured hepatocytes. In addition to actions on the insulin signalling pathway, we examined the direct effect of BDNF on insulin-stimulated 2-deoxy glucose (2-DG) uptake into cultured cells (L6 muscle cells and differentiated 3T3-L1 adipocytes). Insulin increased 2-DG uptake into L6 muscle cells and differentiated 3T3-L1 cells (Table 2). No effect of BDNF was observed on insulin-stimulated 2-DG uptake insulin signalling in cultured cells (primary cultured hepatocytes, L6 muscle cells and differentiated 3T3$\mathrm{L} 1$ adipocytes). The cells preincubated with BDNF $(100 \mathrm{ng} / \mathrm{ml})$ for 2 or $24 \mathrm{~h}$ were stimulated with insulin (100 nmol/l) or saline for $10 \mathrm{~min}$ followed by mea- 
A

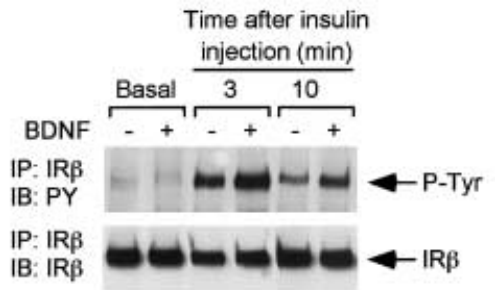

B

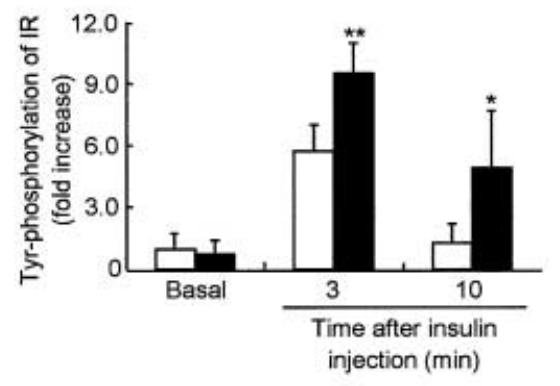

C
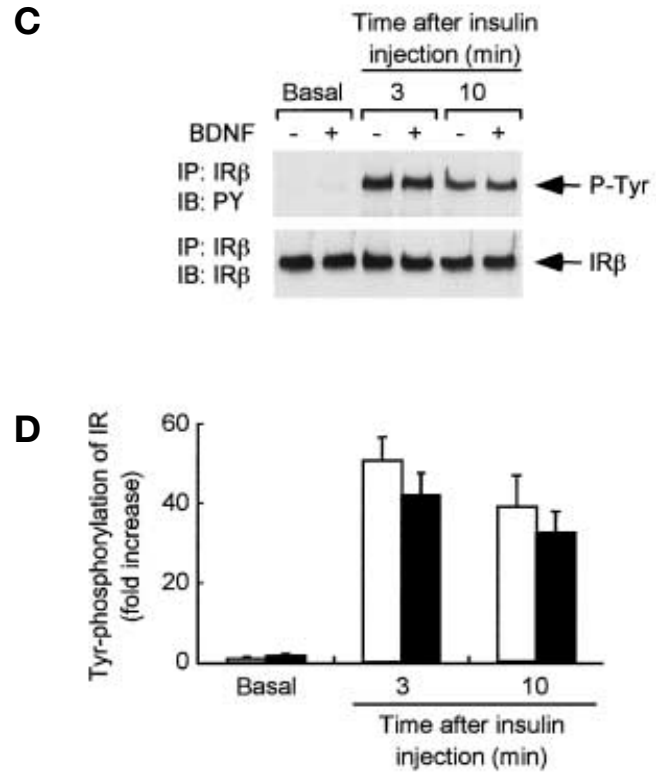

Fig.3. Effect of a single subcutaneous BDNF injection on tyrosine phosphorylation of insulin receptors in streptozotocininduced diabetic mice. Two hours after a single BDNF (70 mg/kg, s.c.) (filled bars) or vehicle (open bars) injection, basal and insulin-stimulated tyrosine phosphorylation of insulin receptor in liver $(\mathbf{A}, \mathbf{B})$ and skeletal muscle $(\mathbf{C}, \mathbf{D})$ were assessed. Equal amounts of protein were immunoprecipitated with anti-insulin receptor $\beta$-subunit antibody followed by SDS-PAGE and western blot analysis of the immunoprecipitates using anti-phosphotyrosine antibody $(\mathbf{A}, \mathbf{C})$. Bar graphs show the densitometry results for liver $(\mathbf{B})$ and skeletal muscle (D). Data are shown as means \pm SD for 5 mice and are expressed as fold increase above that of basal vehicle control. $* p<0.05, * * p<0.01$ vs vehicle by Student's $t$ test
A

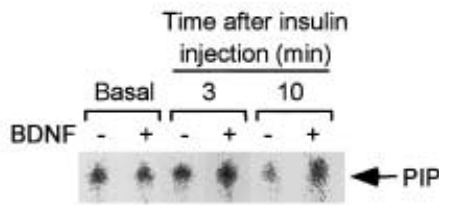

B

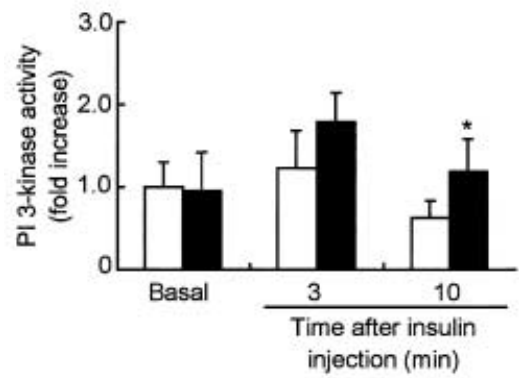

C
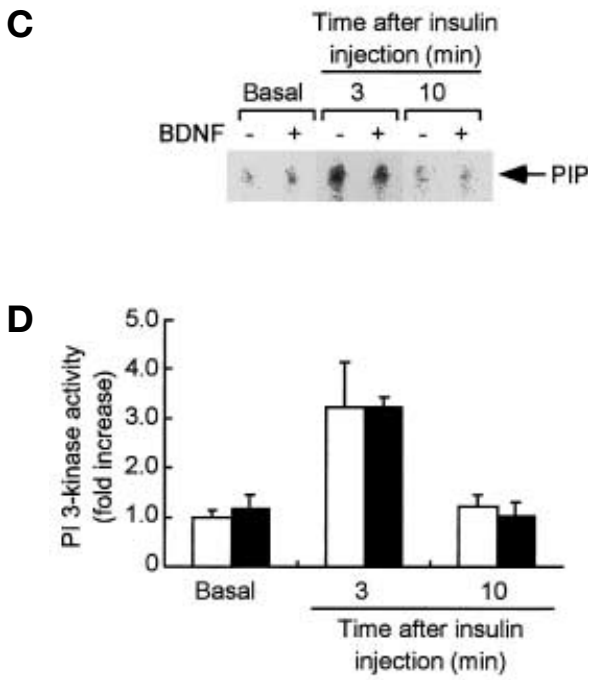

Fig.4. Effect of a single subcutaneous BDNF injection on phosphatidylinositol (P1) 3-kinase activity in streptozotocininduced diabetic mice. Two hours after a single BDNF (70 mg/kg s.c.)(filled bars) or vehicle (open bars) injection, basal and insulin-stimulated PI 3-kinase activity in liver (A, B) and skeletal muscle $(\mathbf{C}, \mathbf{D})$ were assessed. Equal amounts of protein were immunoprecipitated with anti-phosphotyrosine antibody and a PI 3-kinase assay was conducted on the immunoprecipitates $(\mathbf{A}, \mathbf{C})$. Bar graphs show the bio-image analyzer results for liver (B) and skeletal muscle (D). Data are shown as means \pm SD for 5 mice and are expressed as fold increase above that of basal vehicle control. $* p<0.05$ vs vehicle by Student's $t$ test

into these cultured cells (Table 2). We also studied the direct effect of BDNF on glucose metabolism in a primary culture of rat hepatocytes. Glucose concentration in cultured medium of the primary hepatocytes increased, possibly due to gluconeogenesis. After incubation with $10 \mathrm{mmol} / \mathrm{l}$ metformin for $6 \mathrm{~h}$, the glucose concentration in the medium was lower than the untreated control (Table 3). This indicates that 
A

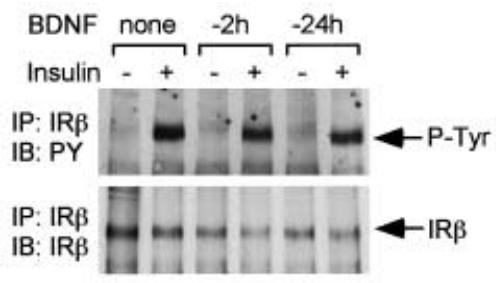

C

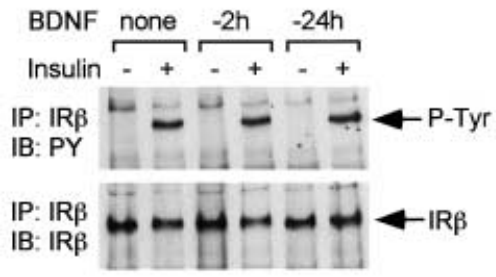

E

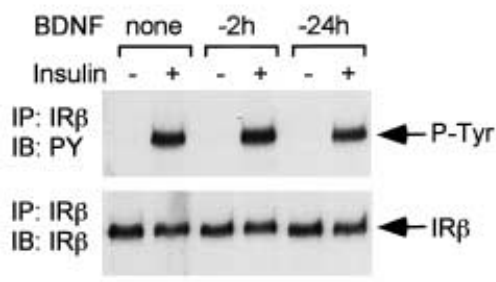

Fig. 5. Effects of BDNF on insulin signalling in cultured cells. After incubation with BDNF $(100 \mathrm{ng} / \mathrm{ml})$ for 2 or $24 \mathrm{~h}$, isolated hepatocytes (A, B), L6 muscle cells $(\mathbf{C}, \mathbf{D})$ and 3T3-L1 adipocytes $(\mathbf{E}, \mathbf{F})$ were stimulated with insulin $(100 \mathrm{nmol} / \mathrm{l})$ for $10 \mathrm{~min}$. Equal protein amounts of cell lysates were immunoprecipitated with anti-insulin receptor $\beta$-subunit antibody followed by SDS-PAGE and western blot analysis of the immunoprecipitates using either anti-phosphotyrosine antibody or anti-insulin receptor $\beta$-subunit antibody $(\mathbf{A}, \mathbf{C}, \mathbf{E})$. Equal amounts of protein were immunoprecipitated with anti-phosphotyrosine antibody and a PI 3-kinase assay was conducted on the immunoprecipitates $(\mathbf{B}, \mathbf{D}, \mathbf{F})$

metformin acts directly on hepatocytes and inhibits gluconeogenesis. In contrast, incubation with 1-100 $\mathrm{ng} / \mathrm{ml} \mathrm{BDNF}$ for $6 \mathrm{~h}$ did not affect the glucose concentration of the cultured medium (Table 3 ).

Rapid effect of intracerebroventricular BDNF injection on insulin signal transduction in streptozotocininduced dabetic mice. Because BDNF showed no obvious effects on insulin action in cultured hepatocytes, myotubles and adipocytes, we examined whether or not the central BDNF injection rapidly affects insulin signalling in vivo. Two hours after intracerebroventricular injection of BDNF or aCSF, insulin was intravenously injected into STZ-mice and then tyrosine phosphorylation of insulin receptor and PI 3-kinase activity in liver and skeletal muscle of the mice were measured. We found that BDNF
B
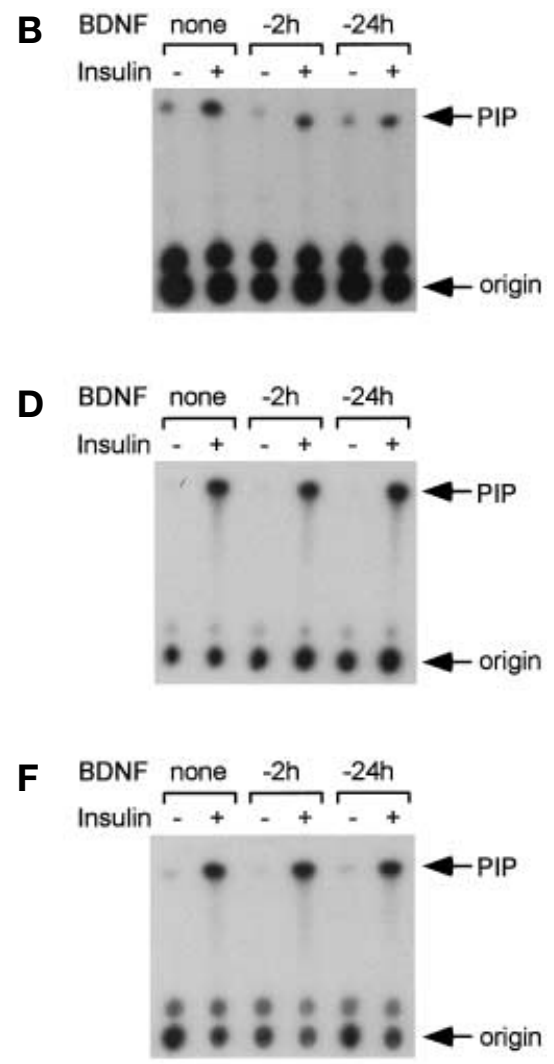

given intracerebroventricularly enhanced insulinstimulated tyrosine phosporylation of insulin receptor and phosphotyrosine-associated PI 3-kinase activity in liver compared with aCSF injection (Fig. 6 A, C). In contrast, BDNF showed no effect on insulinstimulated tyrosine phosphorylation of insulin receptor and PI 3-kinase activity in skeletal muscle (Fig. 6 $\mathrm{B}, \mathrm{D})$. Moreover, to assess the effect of BDNF on insulin signalling in details, we examined the IRS- 1 or IRS-2 associated PI 3-kinase activity in liver. BDNF enhanced insulin-stimulated IRS-2 associated PI 3kinase activity compared with aCSF (Fig. 6 F), although BDNF had no effect on insulin-stimulated IRS-1 associated PI 3-kinase activity (Fig. 6 E).

\section{Discussion}

Previously we have shown that repeated subcutaneous injection of BDNF reduced blood glucose concentrations in obese and hyperinsulinaemic $d b / d b$ mice [8-11]. Because $d b / d b$ mice show decreased insulin responsiveness in peripheral tissues [24], it is possible that enhancement of insulin responsiveness in peripheral tissues reduces blood glucose concentration of $d b / d b$ mice. In this study, we have thus investigated whether BDNF treatment modulates insulin-induced activation of the insulin receptor and its downstream signalling elements in $d b / d b$ mice. Repeated injection of BDNF enhanced insulin-triggered tyrosine phosphorylation of the insulin receptor in 
A

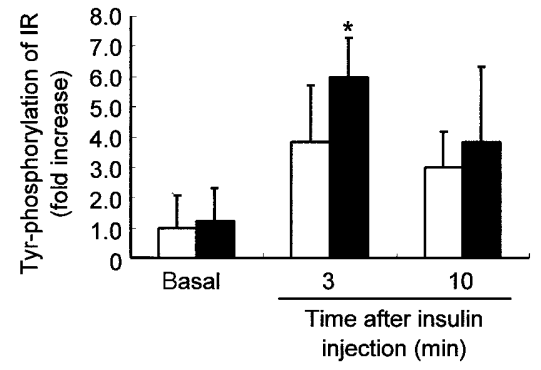

C

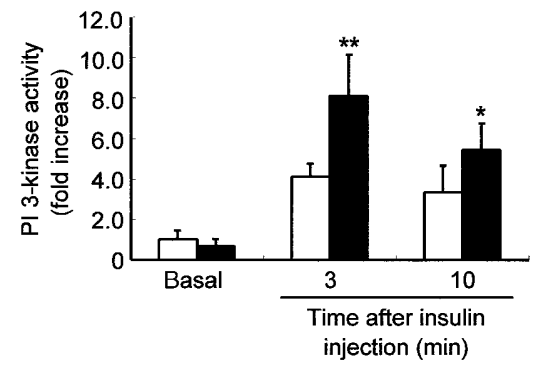

E

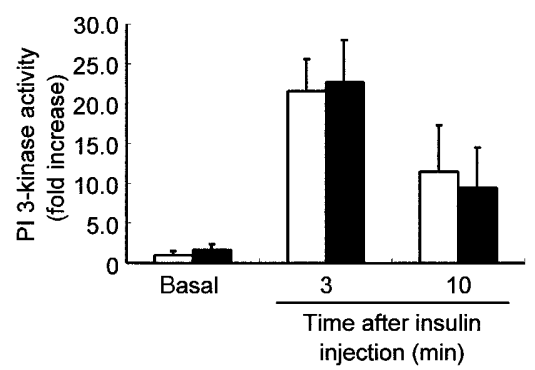

Fig. 6. Effect of a single intracerebroventricular BDNF injection on insulin signalling in streptozotocin-induced diabetic mice. Two hours after a single BDNF ( $5 \mu \mathrm{g} /$ mouse, i.c.v.) (filled bars) or aCSF (open bars) injection, basal and insulin-stimulated tyrosine phosphorylation of insulin receptor and PI 3-kinase activity in liver $(\mathbf{A}, \mathbf{C}, \mathbf{E}, \mathbf{F})$ and skeletal muscle $(\mathbf{B}, \mathbf{D})$ were assessed. Equal amounts of protein were immunoprecipitated with anti-insulin receptor $\beta$-subunit antibody followed by SDS-PAGE and western blot analysis of the immunoprecipitates using anti-phosphotyrosine antibody (A, B). Equal amounts of protein were immunoprecipitated with anti-phosphotyrosine antibody (C, D), anti-IRS-1 antibody (E), and anti-IRS-2 antibody (F), and then a PI 3-kinase assay was conducted on the immunoprecipitates. Data are shown as means \pm SD for 7 or 8 mice and are expressed as fold increase above that of basal aCSF control. * $p<0.05$ vs aCSF by Student's $t$ test

the liver from $d b / d b$ mice without a significant increase in protein content of the insulin receptor. Moreover, repeated injection of BDNF enhanced insulin-stimulated PI 3-kinase activity, which mediates a variety of metabolic actions of insulin $[25,26]$ in the liver, skeletal muscle and interscapular brown adipose tissue, suggesting that BDNF ameliorates insulin responsiveness in peripheral tissues. It should,

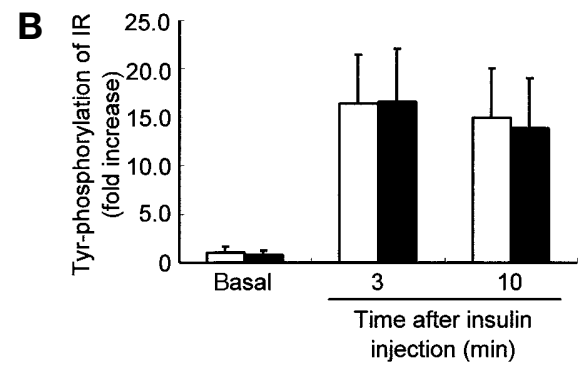

D

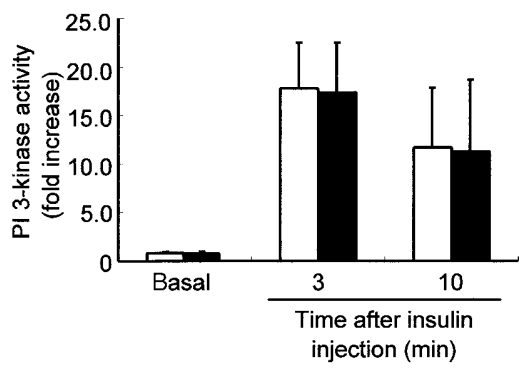

$\mathbf{F}$

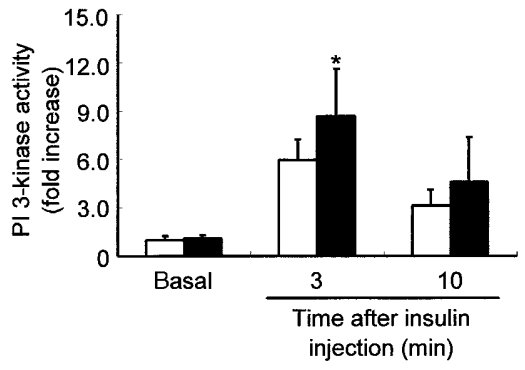

however, be noted that these events could be a secondary effect of reducing glucose toxicity or food intake during the long-term treatment of the hypoglycaemic, anorexic agent. Therefore, it is important to evaluate the possible direct or rapid action of $\mathrm{BDNF}$ on peripheral tissues.

To elucidate whether BDNF exerts a rapid effect on insulin responsiveness, we used a STZ-induced diabetic model. We have previously shown that concomitant injection of BDNF with insulin enhances the hypoglycaemic action of insulin in STZ-mice [11]. We have now shown that BDNF enhanced insulin-induced tyrosine phosphorylation of the insulin receptor in the liver of STZ mice whereas the protein content of the receptor was not altered. Because the effect of BDNF was evident within $2 \mathrm{~h}$ and food was removed after BDNF injection, it is not likely that this effect occurred through anorexic action of BDNF or reducing glucose toxicity. While repeated injection of BDNF enhanced insulin signalling in skeletal muscle in $d b / d b$ mice, no significant rapid effect was observed in skeletal muscle of STZ-mice, suggesting that the effect of BDNF on skeletal muscle of $d b / d b$ mice might be due to ameliorated glucose toxicity caused by long-term treatment. 
Table 2. Effects of BDNF on 2-deoxyglucose uptake in vitro

\begin{tabular}{|c|c|c|c|c|}
\hline & \multicolumn{4}{|c|}{ BDNF (ng/ml) } \\
\hline & 0 & 10 & 100 & 1000 \\
\hline \multicolumn{5}{|l|}{ L6 muscle cells } \\
\hline Insulin-stimulated & $63.9 \pm 2.9$ & $58.4 \pm 4.3$ & $55.0 \pm 3.5$ & $63.6 \pm 5.5$ \\
\hline \multicolumn{5}{|l|}{ 3T3-L1 adipocytes } \\
\hline Basal & $87.4 \pm 9 . S$ & $75.5 \pm 2.9$ & $96.5 \pm 6.2$ & $71.8 \pm 2.7$ \\
\hline Insulin- stimulated & $470.1 \pm 3.6$ & $451.6 \pm 14.6$ & $469.8 \pm 15.3$ & $470.9 \pm 44.4$ \\
\hline
\end{tabular}

Cells were preincubated with BDNF for $24 \mathrm{~h}$. Subsequently 2-deoxy[1,2- $\left.{ }^{3} \mathrm{H}\right]$ glucose uptake was measured under basal or insulinstimulated $(100 \mathrm{nmol} / \mathrm{l})$ conditions. Data are shown as means $\pm \mathrm{SD}$ in units of $\mathrm{pmol} / \mathrm{min}$ per well $(n=3)$

Table 3. Effects of BDNF on glucose production in primary culture of rat hepatocytes

\begin{tabular}{ll}
\hline & Glucose concentration $(\mathrm{mg} / \mathrm{dl})$ \\
\hline Control & $25.6 \pm 0.8$ \\
Metformin & $12.2+0.5$ \\
BDNF $(\mathrm{ng} / \mathrm{ml})$ & \\
1 & $25.4 \pm 2.0$ \\
10 & $25.6+0.4$ \\
100 & $22.7 \pm 0.5$ \\
\hline
\end{tabular}

Primary cultured rat hepatocytes were incubated with BDNF or metformin (10 mmol/l) in glucose free Hank's solution containing $0.1 \%$ fructose and $100 \mathrm{nmol} / \mathrm{l}$ glucagon for $6 \mathrm{~h}$. Glucose concentration in the medium was measured. Data are shown as means $\pm \mathrm{SD}(n=3)$

At this point, we do not know the mechanism how BDNF enhances the tyrosine phosphorylation of the insulin receptor. It has been reported that protein tyrosine phosphatases are involved in the regulation of insulin signalling pathways [27] or that serine phosphorylation of the receptor affects its kinase activity [28]. Therefore, theoretically, BDNF is capable of affecting the insulin receptor kinase through modulating one of these phenomena. Further studies are required to elucidate the mechanism of BDNF on the enhancement of the insulin receptor activity.

Treatment of BDNF resulted in a significant increase in insulin-induced PI 3-kinase activity coprecipitated with IRS-2 with no significant change in that coprecipitated with IRS-1. These results might be explained if IRS-2 possesses stronger affinity to the insulin receptor than IRS-1. The difference in the affinities of IRS proteins to the receptor has not been well characterised. Yeast-two hybrid experiments showed, however, that IRS-1 interacts with the insulin receptor only through the PTB domain whereas IRS-2 interacts with the receptor through the PTB and KRLB domains [29, 30]. It is thus possible that the affinity of each IRS protein to the insulin receptor could be different. We do not, however, exclude the possibility that BDNF affects an unidentified pathway that selectively enhances the signal to IRS-2.

$\mathrm{BDNF}$ is a neurotrophic factor and its receptor, trk $\mathrm{B}$, is predominantly expressed in the central nervous system [31]. In our preliminary experiments, however, a truncated form of BDNF receptor trk B and its association protein, $\mathrm{p} 75$, were found expressed in the cultured cells used in this study (data not shown). We thus assessed the effect of BDNF on the insulin receptor signalling along with glucose metabolism of cultured cells. We did not, however, find any effect of BDNF on the insulin receptor kinase or PI 3-kinase activity induced by insulin. Moreover, incubation with the cells with BDNF had no effects on glucose uptake into cultured muscle cells or adipocytes, or on glucose production in cultured hepatocytes. Although it has been reported that BDNF stimulates tyrosine phosphorylation of IRS-1 and IRS- 2 as well as their association with PI 3-kinase in cultured cerebral cortical neurons [32], BDNF does not seem to affect the insulin signalling or to exert insulin-mimicked actions in these cultured cells.

We have previously shown that intracerebroventricular injection of BDNF in $d b / d b$ mice reduced both blood glucose and food intake at a dose as low as approximately $1 / 100$ of the effective dose with subcutaneous injection [11]. In this study, we have shown that an intracerebroventricular injection of BDNF enhanced insulin responsiveness in the liver of STZmice. These results suggest that the effects of BDNF on reducing glucose concentration and enhancing the insulin signalling occurred through its actions in the central nervous system. This profile of BDNF action reminds us of the anorectic protein, leptin, which rapidly stimulates glucose uptake and glucose turnover in normoglycaemic C57BL mice and hyperglycaemic $o b / o b$ mice following intracerebroventricular infusion [33, 34]. Intrahypothalamic injection of leptin acutely enhances glucose uptake in peripheral tissues of normal rats, an effect which is enhanced synergistically with insulin $[35,36]$. In addition, some reports have shown that long-term treatment of leptin also enhances insulin sensitivity [37, 38].

Although leptin drastically reduces body weight in leptin-deficient $o b / o b$ mice and normal rodents it had not been clear whether leptin has hypoglycaemic action against altered glucose metabolism. But recently it has been reported that the hypoglycaemic action of insulin increased in transgenic mice overexpressing 
leptin in liver compared with non-transgenic littermates [39]. In liver and skeletal muscle from these transgenic mice, insulin-triggered tyrosine phosphorylation of insulin receptors and PI 3-kinase activity was enhanced [39]. This profile of leptin is similar to our findings on the action of BDNF. Both leptin and BDNF might share the same mechanism in regulating insulin responsiveness and glucose metabolism.

In summary, we have shown here that BDNF enhances the insulin receptor signalling in the liver of STZ-induced diabetic mice and that this effect of BDNF probably occurred through its action in the central nervous system. At this point, it is not clear if the modulation of the insulin signalling in the liver is related to the enhancement of hypoglycaemic action of insulin by BDNF. Recent findings, however, on the liver-specific insulin receptor knockout mice [40] or on IRS-2 knockout mice [41] imply that the insulin signalling or the IRS-2 mediated signalling in the liver is importart to regulate glucose homeostasis. Very recently, it has been reported that mice, being heterozygous for targeted disruption of the BDNF gene, exhibit hyperphagia and obesity $[42,43]$. Moreover, these mice show hyperleptinemia and hyperinsulinaemia [43]. These interesting results further support the physiological significance of BDNF in weight control and glucose metabolism. Further detailed studies will be needed to show the molecular mechanism of BDNF in regulating glucose metabolism.

\section{References}

1. Lindsay RM, Wiegand SJ, Altar CA, DiStefano PS (1994) Neurotrophic factors: from molecule to man. Trends Neurosci 17: 182-190

2. Skup MH (1994) BDNF and NT-3 widen the scope of neurotrophin activity: pharmacological implications. Acta Neurobiol Exp (Warsz.) 54: 81-94

3. Barbacid M (1995) Neurotrophic factors and their receptors. Curr Opin Cell Biol 7: 148-155

4. Lewin GR, Barde YA (1996) Physiology of the neurotrophins. Annu Rev Neurosci 19: 289-317

5. Thoenen H, Castrén E, Berzaghi M, Blöchl A, Lindholm D (1994) Recent advances in the treatment of neurodegenerative disorders and cognitive dysfunction. In: Racagni G, Brunello N, Langer SZ (ed) Int Acad Biomed Drug Res. Karger, Basel, 7: 197-203

6. Sendtner M, Holtman B, Hughes RA (1996) The response of motoneurons to neurotrophins. Neurochem Res 21: 831-841

7. Yuen EC, Mobley WC (1996) Therapeutic potential of neurotrophic factors for neurological disorders. Ann Neurol 40: 346-354 eV

8. Ono M, Ichihara J, Nonomura Tet al. (1997) Brain-derived neurotrophic factor reduces blood glucose level in obese diabetic mice but not in normal mice. Biochem Biophys Res Commun 238: 633-637

9. Tonra JR, Ono M, Liu X et al. (1999) Brain derived neurotrophic factor improves blood glucose control and alleviates fasting hyperglycemia in C57BLKS-lepr ${ }^{\mathrm{db}} / \mathrm{lepr}^{\mathrm{db}}$ mice. Diabetes 48: 588-594
10. Ono M, Itakura Y, Nonomura T et al. (2000) Intermittent administration of Brain-derived neurotrophic factor ameliorates glucose metabolism in obese diabetic mice. Metabolism 49: 129-133

11. Nakagawa T, Tsuchida A, Itakura Y et al. (2000) Brain-derived neurotrophic factor (BDNF) regulates glucose metabolism by modulating energy balance in diabetic mice. Diabetes 49: 436-444

12. Soll AH, Kahn CR, Neville DM Jr, Roth J (1975) Insulin receptor deficiency in genetic and acquired obesity. J Clin Invest 56: 769-780

13. DeFronzo RA, Bonadonna RC, Ferrannini BE (1992) Pathogenesis of NIDDM. Diabetes Care 15: 318-368

14. Heydrick SJ, Jullien D, Gautier N et al. (1993) Defect in skeletal muscle phosphatidylinositol 3-kinase in obese insulin-resistant mice. J Clin Invest 91: 1358-1366

15. Chua SC Jr, Chung WK, Wu-Peng XS et al. (1996) Phenotypes of mouse diabetes and rat fatty due to mutations in the OB (leptin) receptor. Science 271: 994-996

16. King PA, Horton ED, Hirschman MF, Horton ES (1992) Insulin resistance in obese Zucker rat ( $f a / f a)$ skeletal muscle is associated with a failure of glucose transporter translocation. J Clin Invest 90: 1568-1575

17. Kahn CR, Neville DM Jr, Roth J (1973) Insulin receptor interaction in the obese hyperglycemic mouse. A model of insulin resistance. J Biol Chem 248: 244-250

18. Folli F, Saad MJA, Backer JM, Kahn CR (1993) Regulation of phosphatidylinositol 3-kinase activity in liver and muscle of animal models of insulin-resistant and insulin-deficient diabetes mellitus. J Clin Invest 92: 1787-1794

19. Kerouz NJ, Hörsch D, Pons S, Kahn CR (1997) Differential regulation of insulin receptor substrate-1 and -2 (IRS1 and IRS-2) and phosphatidylinositol 3-kinase isoforms in 1iveF and muscle of the obese diabetic (ob/ob) mouse. J Clin Invest 100: 3164-3172

20. Fujiwara T, Yoshioka S, Yoshioka T, Ushiyama I, Horikoshi H (1988) Characterization of new oral antidiabetic agent CS-045. Diabetes 37: 1549-1558

21. Sugiyama Y, Taketomi S, Shimura Y, Ikeda H, Fujita T (1990) Effect of pioglitazone on glucose and lipid metabolism in Wistar fatty rats. Arzneimittelforschung 40: 263-267

22. Hayakawa T, Shiraki T, Morimoto T, Shii K, Ikeda H (1996) Pioglitazone improves insulin signaling defects in skeletal muscle from Wistar fatty $(f a / f a)$ rats. Biochem Biophys Res Commun 223: 439-444

23. Seglen PO (1976) Preparation of isolated rat liver cells. Methods Cell Biol 13: 29-83

24. Kodama H, Fujita M, Yamaguchi I (1994) Development of hyperglycemia and insulin resistance in conscious genetically diabetic (C57BL/Ksj-db/db) mice. Diabetologia 37: 739-744

25. Holman GD, Kasuga M (1997) From receptor to transporter: insulin signaling to glucose transport. Diabetologia 40 : 991-1003

26. Shepherd PR, Withers DJ, Siddle K (1998) Phosphoinositide 3-kinase: the key switch mechanism in insulin signaling. Biochem J 333: 471-490

27. Goldstein BJ (1992) Protein-tyrosine phosphatases and the regulation of insulin action. J Cell Biochem 48: 33-42

28. Takayama S, White MF, Kahn CR (1988) Phorbol ester-induced serine phosphorylation of the insulin receptor decreases its tyrosine kinase activity. J Biol Chem 263: 3440-3447

29. Eck MJ, Dhe-Paganon S, Trub T, Nolte RT, Shoelson SE (1996) Structure of the IRS-1 PTB domain bound to the juxtamembrane region of the insulin receptor. Cell 85: 695-705 
30. Sawka-Verhelle D, Baron V, Mothe I, Filloux C, White MF, Van Obberghen E (1997) Tyr624 and Tyr628 in insulin receptor substrate-2 mediate its association with the insulin receptor. J Biol Chem 272: 16414-16420

31. Shelton DL, Sutherland J, Gripp J et al. (1995) Human trks: Molecular cloning, tissue distribution, and expression of extracellular domain immunoadhesins. J Neurosci 15: 477-491

32. Yamada M, Ohnishi H, Sano S, Nakatani A, Ikeuchi T, Hatanaka H (1997) Insulin receptor substrate (IRS)-1 are tyrosine-phosphorylated and associated with phosphatidylinositol 3-kinase in response to brain-derived neurotrophic factor in cultured cerebral cortical neurons. J Biol Chem 272: 30334-30339

33. Kamohara S, Burcelin R, Halaas JL, Friedman JM, Charron MJ (1997) Acute stimulation of glucose metabolism in mice by leptin treatment. Nature 389: 374-377

34. Burcelin R, Kamohara S, Li J, Tannenbaum GS, Charron MJ, Friedman JM (1999) Acute intravenous leptin infusion increases glucose turnover but not skeletal muscle glucose uptake in $o b / o b$ mice. Diabetes 48: 1264-1269

35. Minokoshi Y, Haque MS, Shimazu T (1999) Microinjection of leptin into the ventromedial hypothalamus increases glucose uptake in peripheral tissues in rats. Diabetes 48: 287-291

36. Haque MS, Minokoshi Y, Hamai M, Iwai M, Horiuchi M, Shimazu T (1999) Role of the sympathetic nervous system and insulin in enhancing glucose uptake in peripheral tis- sues after intrahypothalamic injection of leptin in rats. Diabetes 48: 1706-1712

37. Cusin I, Zakrzewska KE, Boss O et al. (1998) Chronic central leptin infusion enhances insulin-stimulated glucose metabolism and favors the expression of uncoupling proteins. Diabetes 47: 1014-1019

38. Shi ZQ, Nelson A, Whitcomb L, Wang J, Cohen AM (1998) Intracerebroventricular administration of leptin markedly enhances insulin sensitivity and systemic glucose utilization in conscious rats. Metabolism 47: 1274-1280

39. Ogawa Y, Masuzaki H, Hosoda K et al. (1999) Increased glucose metabolism and insulin sensitivity in transgenic skinny mice overexpressing leptin. Diabetes 48: 1822-1829

40. Michael MD, Kulkarni RN, Postic C et al. (2000) Loss of insulin signaling in hepatocytes leads to severe insulin resistance and progressive hepatic dysfunction. Mol Cell 6: 87-97

41. Kubota N, Tobe K, Terauchi Y et al. (2000) Disruption of insulin receptor substrate 2 causes type 2 diabetes because of liver insulin resistance and lack of compensatory $\beta$-cell hyperplasia. Diabetes 49: 1880-1889

42. Lyons WK, Mamounas LA, Ricaurte GA et al. (1999) Brain-derived neurotrophic factor-deficient mice develop aggressiveness and hyperphagia in conjunction with brain serotonergic abnormalities. Proc Natl Acad Sci USA 96: 15239-15244

43. Kernie SG, Liebl DJ, Parada LF (2000) BDNF regulates eating behavior and locomotor activity in mice. EMBO J 19: 1290-1300 